\title{
Dynamics of Plankton Community in Banahao-Palhi River in Leyte, Philippines
}

\author{
Marita I. Galinato and Julissah C. Evangelio \\ Department of Biological Sciences, Visayas State University, Visca, Baybay City, Leyte
}

\section{ABSTRACT}

Plankton consists of microscopic plants "phytoplankton" and animals "zooplankton". They play a principal role in aquatic food web and indicators of ecosystem change. Phytoplankton are the food source for zooplankton, and together, form the base of ocean and river food chains. In Leyte, few researches have been conducted in plankton specifically in river systems. The study was conducted to understand phytoplankton dynamics by first studying their occurrence, composition, and abundance.

Three sampling sites were established along Banahao-Palhi river during dry and wet seasons. A total of 162 plankter samples were analyzed in the laboratory. Dry season sampling showed 99 pelagic algae belonging to 58 genera across sites. In all sites, the commonly occurring diatoms were Biddulphia, Meridion, and Synedra. For the green algae (Chlorophyceae) group, Groenbladia was the most common genus, while in the blue-greens (Cyanophyceae), Nostoc. In wet season, 165 pelagics in 68 genera were observed. Bacillariophyceae got the most number of pelagic algae in all sites for both seasons. For true zooplankton, eight families were recorded during the dry season with four, belonging to Rotifera, two under Copepoda and one, from Cladocera. Similar groups were found during wet season. Larvae of insects and benthics were found part of the zooplankton community. Insect groups include Orders Coleoptera, Diptera, Ephemeroptera, Megaloptera, Plecoptera and Trichoptera. Non-insect groups include Arachnida, Amphipoda, Gastropoda and fish larvae. The Rotifera is the commonly occurring holoplankton with six genera identified. However, the copepods were the most abundant in Brgy. Palhi while protozoans, in Brgy. Banahao.

Keywords: abundance, Banahao-Palhi river, holoplankton, pelagic algae, phytoplankton

\section{INTRODUCTION}

Plankton forms a small biota of microscopic pelagic algae (phytoplankton) and microscopic animals (zooplankton) in aquatic systems. The phytoplankton constitutes a large and very diverse

Correspondence: M.I. Galinato Address: Department of Biological Sciences, Visayas State University, Visca, Baybay City, Leyte E-mail:migalinato@yahoo.com.ph Tel. No.: (053) 563-7536

DOI: $10.32945 /$ atr3829.2016 
assemblage of microalgae and occurs predominantly in freshwater (Bowling, 2009). Zooplankton includes holoplankton (true zooplankton) and meroplankton (organisms that spend as zooplankton in their early life stage such as insect larvae). These microfauna are present in most freshwater habitats ranging from small ponds to rivers and lakes (Kobayashi etal.2009).

The availability of planktonic organisms in a certain body of water can give an idea of the productivity of that particular system. Phytoplankton bloom could indicate nutrient enriched habitats which may pose benefit or threat to these aquatic systems. In such ecosystem, the zooplankton as the primary consumer plays an important role in regulating the growth and multiplication or abundance of these microbial algae through grazing.

In Leyte, survey and identification studies on algae have been limited in Lago-lago (Valenzona, 2005) and Calbiga-a (Ludevese, 2005) rivers. In view of this, there is still a considerable gap in understanding the ecology and the biophysical condition of the rivers. Banahao-Palhi River is one of the largest and among the many rivers of Baybay, Leyte that provides important source of livelihood to nearby residents. A detailed investigation on the biological components specifically the composition and dynamics of plankton communities in this river has not yet been done, hence, this study.

\section{MATERIALS AND METHODS}

\section{Site Survey}

A reconnaissance survey was conducted to determine the three sampling sites for the study: upper stream, mid stream and lower stream. In each site, a $100-\mathrm{m}$ transect line was laid and three stations were established: $0 \mathrm{~m}, 50 \mathrm{~m}$ and $100 \mathrm{~m}$. In each station, the left, the middle and the right sides of the river were towed using a plankton net for phytoplankton and zooplankton collections.

\section{Sample Collection}

Two sampling periods were done, one during the dry season and another, wet season. Dry season sampling was conducted in May, 2014 while the wet season, in October, 2014.

Plankton samples were collected by horizontally towing a plankton net with $80 \mu \mathrm{m}$ mesh size. Three replicate tows in each point (left, middle and right side of the river) with a total of nine replicates per station were made. A total of 27 samples were collected for phytoplankton and another 27 samples for zooplankton. The samples were placed in properly labeled containers and preserved with Lugol's solution (H20:1000 ml, I2:1gm, Kl: $5 \mathrm{gm})$. This preservative stained plankton cells for better visualization and identification. Samples were kept in a box, away from the sunlight as this would degrade the Lugol's solution. All samples were brought 
directly to the Department of Biological Science Laboratory for analyses.

Physico-chemical parameters such as temperature, $\mathrm{pH}$, current velocity and depth were recorded during the wet season sampling period.

\section{Laboratory Analysis and Identification of Plankton}

In the laboratory, three aliquots were analyzed per phytoplankton and zooplankton samples. A total of 81 samples were analyzed for phytoplankton and another 81 samples for zooplankton. Identification was up to genus level for majority of the pelagic algae, while some, were identified up to species. Zooplankton composition was grouped into holoplankton and meroplankton. The true zooplankton was identified up to family level, while some were determined up to genus. The meroplankton was grouped into insect and non-insect groups. For the insect and non-insect group larvae, identification was up to the level of family only. Occurrence and composition of the plankton among the three sampling sites was recorded and abundance was estimated.

The phytoplankton were identified using the Manual of Freshwater Algae by Whitford and Schumacher (1973). The laboratory manual in Limnology class at the Department of Biological Sciences, Visayas State University, Visca, Baybay City, Leyte and images of algae downloaded from the internet (www.algaebase.com) were also used. The zooplankton were identified using the Guide to Identification of Rotifers, Cladocerans and Copepods by Shiel (1995), Practical Guide for Identifying Freshwater Zooplankton by Witty (2004), and identification for macroinvertebrates were done using the Field Guide to Aquatic Invertebrates (http://www.dep.wv.gov/sos).

\section{RESULTS}

\section{Site Characterization}

Three barangays were chosen as collection sites for plankton study. These were located in Brgys. Banahao, Biasong and Palhi (Figure 1).

Site 1 was located in Brgy. Banahao (N 10 37' 40.6" E 124 50' 5.7") at an elevation of $95 \mathrm{ft}$, where the upstream part of the river was situated. The substrate was sandy, with plenty of boulders and clear fresh water. Presence of macroinvertebrates in the area like mollusks and small crabs were noted. Juvenile fish species were also observed. Along the riparian side, big trees of different species as well as understory associates could be found. The site was clean because of minimal intervention by human activities. The midstream portion at an elevation of $55 \mathrm{ft}$, is located in Brgy. Biasong (N10 39' 9.11" E $\left.124^{\circ} 49^{\prime} 11.2^{\prime \prime}\right)$ and designated as Site 2. The sampling area was near domestic activities such as bathing (of humans and carabaos) and washing clothes so that presence of some cellophane wrappers, soap cases and other debris was evident. Medium size rocks and 
sandy substrate characterized the sampling area. A dominant benthic alga, Cladophora, grow profusely on rocks in the site. Site 3 is located in Brgy. Palhi (N $10^{\circ} 39^{\prime} 3.0^{\prime \prime}$ E $124^{\circ} 48^{\prime} 47.9^{\prime \prime}$ ) with elevation of $38 \mathrm{ft}$. It constituted the downstream portion of the river where freshwater meets the saltwater from the sea during high tide. Anthropogenic activities were evident in the area, so human intervention played a big role in the use of the river. The substrate was a mixture of sand and rock. The edge of the river was lush with vegetation of different plant species.

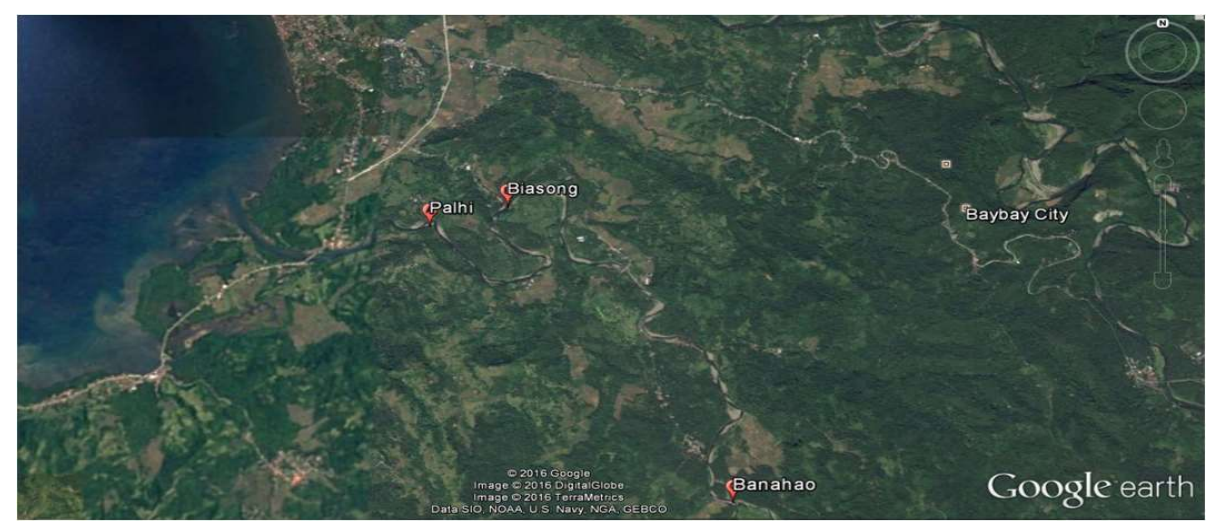

Figure 1. Map of Baybay showing the sampling sites: Barangays Banahao (N $10^{\circ} 37^{\prime} 40.6^{\prime \prime} \mathrm{E}$ $124^{\circ} 50^{\prime}$ 5.7"; Elevation $95 \mathrm{ft}$ ), Biasong (N10³9' 9.11" E 124 49' 11.2"; Elevation 55ft), and Palhi (N 10³9' 3.0" E $124^{\circ} 48^{\prime} 47.9^{\prime \prime}$; Elevation 38ft)

\section{Dry Season Sampling}

\section{Plankton Composition and Distribution}

Across sites, a total of 99 free-floating or pelagic algae belonging to 58 genera and six different classes (Table 1 ) and a total of 20 zooplankton from different families (Table 2) were collected and analyzed. For holoplankton, four major groups were identified across all sites which included Cladocera, Copepoda, Protozoa and Rotifera while meroplankton was composed of insect larvae and a few non-insect larvae. The occurrence of the zooplankton in each point in the sampling site is also presented in Table 2 .

\section{Site 1. Brgy. Banahao}

A total of 39 genera of pelagic algae were collected in the three sampling points at the upstream portion of the river in Brgy.Banahao. This represented six classes of free-floating algae, which included Bacillariophyceae (the diatoms), Charophyceae (the stoneworts), Chlorophyceae (the greens), Chrysophyceae (the diatoms), Cyanophyceae (the blue-greens) and Rhodophyceae (the reds) (Table 1). Bacillariophyceae had the most number (14) of representative genera followed by Chlorophyceae (13), then by Cyanophyceae (11), 
Chrysophyceae (2) and lastly, by Charophyceae (1) and Rhodophyceae (1). In the diatom group, Class Bacillariophyceae, the following genera were found to be widely occurring: Biddulphia, Fragilaria, Meridion, Navicula, Synedra,and Tabellaria (Figure 2). All of them were found present in the three sampling points. In the group of green algae, the genera Groenbladia and Mesotaenium were the most common (Figure 3). For the blue-greens, Nostoc, was dominant, occurring in all sampling points (Figure 4). Benthic forms of algae were also recorded. Cladophora, was the most common, found attached on rock substrate. Also, presence of blue-green alga, Nostoc was monitored attached on small stones.

Table 1. Pelagic algae collected in the three sites at three sampling points of the river during dry season

\begin{tabular}{|c|c|c|c|}
\hline Class/Genus & Site 1 & Site 2 & Site 3 \\
\hline \multicolumn{4}{|l|}{ Bacillariophyceae } \\
\hline Achnanthes & + & + & + \\
\hline Amphora & + & - & + \\
\hline Biddulphia & + & + & + \\
\hline Capartogamma & - & + & - \\
\hline Cocconeis & + & + & - \\
\hline Cyclotella & - & + & + \\
\hline Cymatopleura & + & - & - \\
\hline Epithemia & + & + & + \\
\hline E. zebra & - & + & - \\
\hline Eunotia & + & - & + \\
\hline Fragilaria & + & + & + \\
\hline Gomphonema & + & - & - \\
\hline Licmophera & + & - & - \\
\hline Meridion & + & + & + \\
\hline Navicula & + & + & + \\
\hline Nitzschia & - & + & - \\
\hline Pinnularia & - & - & + \\
\hline Pleurosigma & - & + & - \\
\hline Surirella & - & + & - \\
\hline Synedra & + & + & + \\
\hline Tabellaria & + & + & + \\
\hline \multicolumn{4}{|l|}{ Charophyceae } \\
\hline Chara & + & + & - \\
\hline \multicolumn{4}{|l|}{ Chlorophyceae } \\
\hline Ankistrodesmus & - & - & + \\
\hline Arthroocystis & - & + & - \\
\hline Chlorella & - & + & - \\
\hline Closterium & + & + & + \\
\hline Cosmarium & + & - & - \\
\hline Groenbladia sp. & + & - & - \\
\hline Groenbladia sp. & + & - & - \\
\hline Groenbladia sp. & + & - & - \\
\hline Groenbladia sp. & + & - & - \\
\hline Groenbladia & - & + & + \\
\hline
\end{tabular}


Table 1. Continuation

\begin{tabular}{|c|c|c|c|}
\hline Class/Genus & Site 1 & Site 2 & Site 3 \\
\hline G. taylorii & - & + & - \\
\hline Hematococcus & + & - & - \\
\hline Hyalotheca & + & + & - \\
\hline Mesotaenium & + & - & - \\
\hline Microspora & + & + & + \\
\hline Microthamnion & - & + & - \\
\hline Pediastrum & - & + & - \\
\hline Scenedesmus & - & + & + \\
\hline Spirogyra & - & - & + \\
\hline Staurastrum & + & - & - \\
\hline Stephanosphaera & - & + & - \\
\hline Trebouxia & - & + & - \\
\hline Treubria & - & + & - \\
\hline Triploceras & + & - & - \\
\hline Ulothrix & - & + & - \\
\hline Volvox & + & - & + \\
\hline \multicolumn{4}{|l|}{ Chrysophyceae } \\
\hline Eirmodesmus & + & - & - \\
\hline Synura & + & - & - \\
\hline \multicolumn{4}{|l|}{ Cyanophyceae } \\
\hline Chroococcus & + & - & - \\
\hline Dactylococcopsis & + & - & + \\
\hline Entophysalis & + & - & - \\
\hline Gloeothece & + & - & - \\
\hline Merismopedia & + & + & - \\
\hline Nostoc & + & + & + \\
\hline Polycystis & + & - & - \\
\hline Schizothrix & + & - & + \\
\hline Spirulina & + & - & + \\
\hline Synechococcus & + & - & - \\
\hline Stigonema & + & - & - \\
\hline Rhodophyceae & & & \\
\hline Boldia & - & + & - \\
\hline Compsopogon & + & - & - \\
\hline Rhodochorton & - & + & - \\
\hline Total Number of Pelagic Algae (Genera) & $\begin{array}{c}42 \\
(39)\end{array}$ & $\begin{array}{c}34 \\
(32)\end{array}$ & $\begin{array}{c}23 \\
(23)\end{array}$ \\
\hline
\end{tabular}

Legend: + Present; - Absent

Site 1: Banahao; Site 2: Biasong; Site 3: Palhi

There were a total of twenty (20) zooplankton occurring in Brgy. Banahao distributed in all three sampling points (Table 2). Of the 20, 11 were identified belonging to different families and six of these represented the major groups of true zooplankton: Daphniidae, Harpacticoida, Brachioniidae, Euclanidae, and Testudinellidae. Three major insect groups were identified belonging to five families. Three were Diptera, 
one Ephemeroptera and one Plecoptera. The five families included Chironomidae, Simuliidae, Tipuliidae, Baetidae and Capniidae. Five unidentified insect larvae were also noted. An arachnid categorized as noninsect group under Family Hydracnidae was also identified from the samples. Figure 5 showed these different representative species.

Table 2. Occurrence of zooplankton collected in the three sites of the river during dry season

\begin{tabular}{|c|c|c|c|c|c|}
\hline Major Taxon & Family & Genus & Site 1 & Site 2 & Site 3 \\
\hline \multicolumn{6}{|l|}{ Holoplankton } \\
\hline Cladocera & Daphniidae & Daphnia & + & + & + \\
\hline \multirow[t]{3}{*}{ Copepoda } & Cyclopoida & & - & + & + \\
\hline & Harpacticoida & & + & + & + \\
\hline & Nauplius & & + & - & + \\
\hline \multirow[t]{6}{*}{ Rotifera } & Brachioniidae & Brachionus & + & + & + \\
\hline & & Keratella & + & + & - \\
\hline & Euclanidae & Euclanus & + & - & - \\
\hline & Lecanidae & Lecane & + & + & + \\
\hline & Mytilinidae & Mytilina & - & + & + \\
\hline & Testudinellidae & Testudinella & + & + & + \\
\hline Protozoa & & & + & + & + \\
\hline Total Number & & & 9 & 9 & 9 \\
\hline \multicolumn{6}{|l|}{ Meroplankton } \\
\hline \multicolumn{6}{|l|}{ Insect Groups } \\
\hline Coleoptera & & & - & + & + \\
\hline \multirow[t]{3}{*}{ Diptera } & Chironomidae & & + & + & + \\
\hline & Simuliidae & & + & + & - \\
\hline & Tipulidae & & + & + & - \\
\hline Ephemeroptera & Baetidae & & + & + & + \\
\hline Megaloptera & & & - & + & - \\
\hline Plecoptera & Capniidae & & + & - & - \\
\hline Trichoptera & Rhyacophilidae & & - & + & - \\
\hline \multirow[t]{5}{*}{ Unidentified } & 1 & & + & + & - \\
\hline & 2 & & + & - & - \\
\hline & 3 & & + & - & - \\
\hline & 4 & & + & - & - \\
\hline & 5 & & + & - & - \\
\hline Non-insect groups & & & 10 & 8 & 3 \\
\hline Arachnida & Hydrachnidae & & + & + & + \\
\hline Fish Larvae & & & - & + & - \\
\hline Gastropod Larvae & & & - & - & + \\
\hline Total Number & & & 1 & 2 & 2 \\
\hline Overall Total & & & 20 & 19 & 14 \\
\hline
\end{tabular}

Legend: + Present; - Absent

Site 1: Banahao; Site 2: Biasong; Site 3: Palhi 


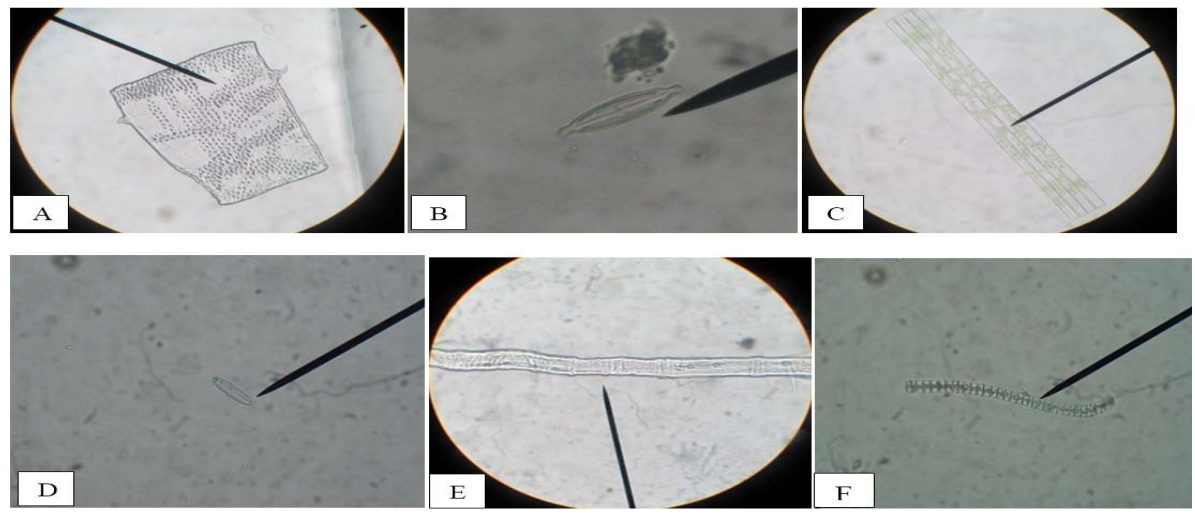

Figure 2. Genera of widely occurring diatoms (Bacillariophyceae) in Brgy. Banahao: A. Biddulphia B. Fragilaria C. Meridion D. Navicula E. Synedra F. Tabellaria (400X)

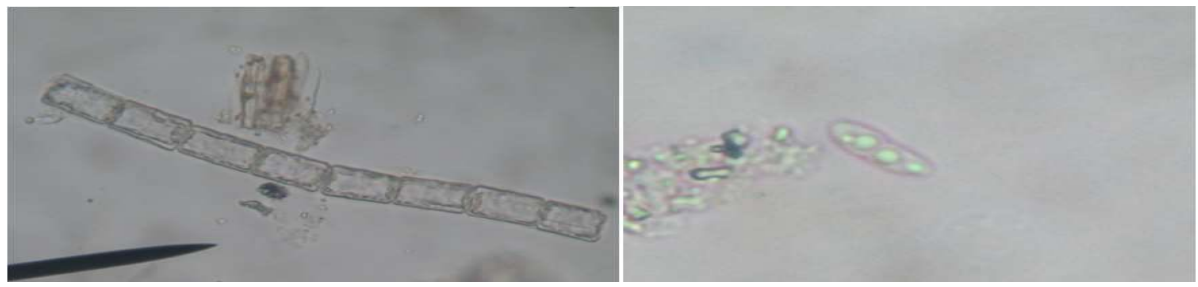

Figure 3. Genera of common green algae (Chlorophyceae) in Brgy. Banahao: Left, Groenbladia Right, Mesotaenium (400X)

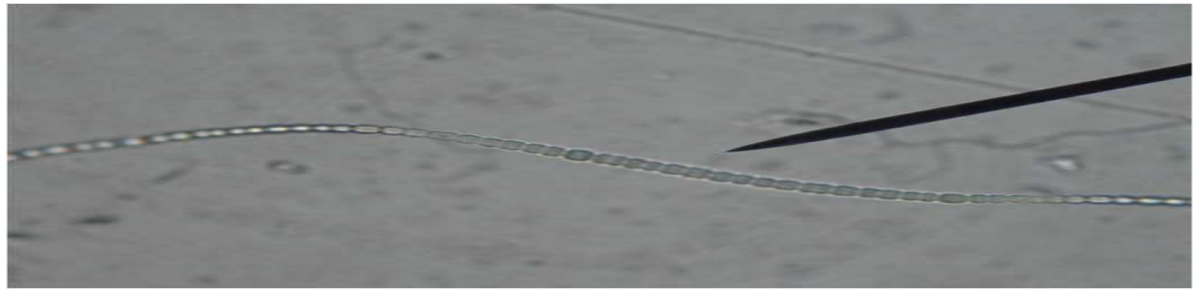

Figure 4. Genus of blue-green alga (Cyanophyceae) common in Brgy. Banahao: Nostoc $(400 X)$

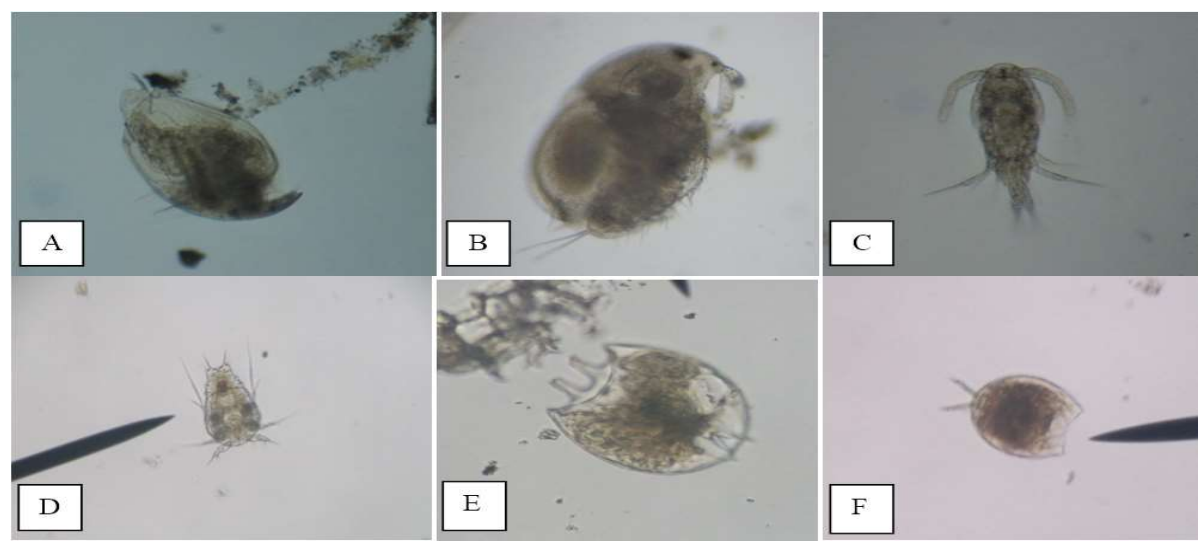

Figure 5. Representative groups of holoplankton in Brgy. Banahao, Brgy.Biasong and Brgy. Palhi: Cladocera(A-B); Copepoda (C-D); and Rotifera (E-F).Total Magnification: 100x 
Site 2. Brgy. Biasong

At the midstream portion of the river in Brgy. Biasong, there were 32 genera of pelagic algae identified (Table 1). This number represented five classes of free-floating algae in the three sampling sites within the river. The classes of algae included Bacillariophyceae, Charophyceae, Chlorophyceae, Cyanophyceae and Rhodophyceae. Of the five classes, Bacillariophyceae, had the most number (14) of genera. This was followed by Chlorophyceae with 13. Cyanophyceae and Rhodophyceae had two genera each while Charophyceae, one. In Bacillariophyceae, there were six widely occurring genera found in the three sampling points. These were the following: Achnanthes, Biddulphia, Fragilaria, Meridion, Synedra and Tabellaria (Figure 6). The genus Chara belonging to Charophyceae, was the most common pelagic alga occurring in the left, right and middle sampling points (Figure 7a). In Chlorophyceae, Groenbladia and Scenedesmus were present in all sampling points (Figure 8) while Nostoc was the most commonly observed in Cyanophyceae (Figure 7b).
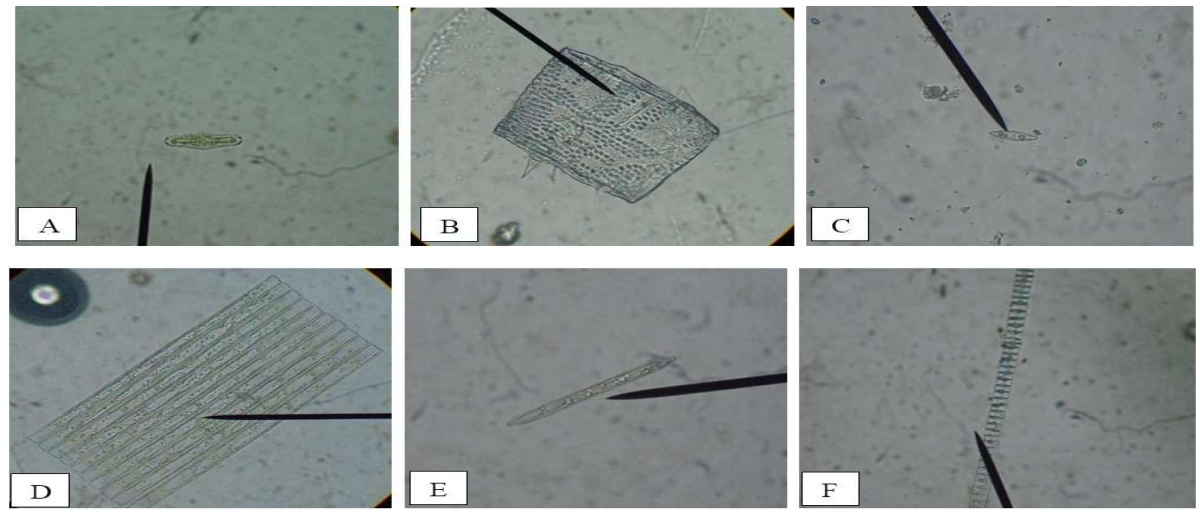

Figure 6. Genera of widely occurring diatoms (Bacillariophyceae) in Brgy. Biasong (A. Achnanthes B.Biddulphia C. Fragilaria D. Meridion E.Synedra F. Tabellaria, 400X)
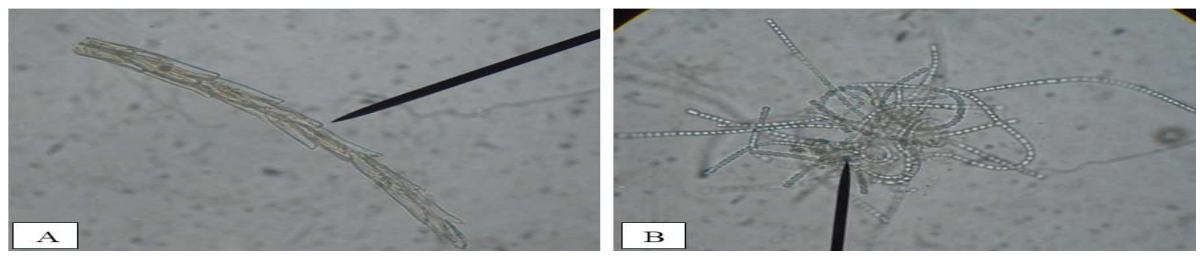

Figure 7. Genera of widely occurring algae in Brgy. Biasong (A. Chara-Charophyceae B. Nostoc-Cyanophyceae, 400X)
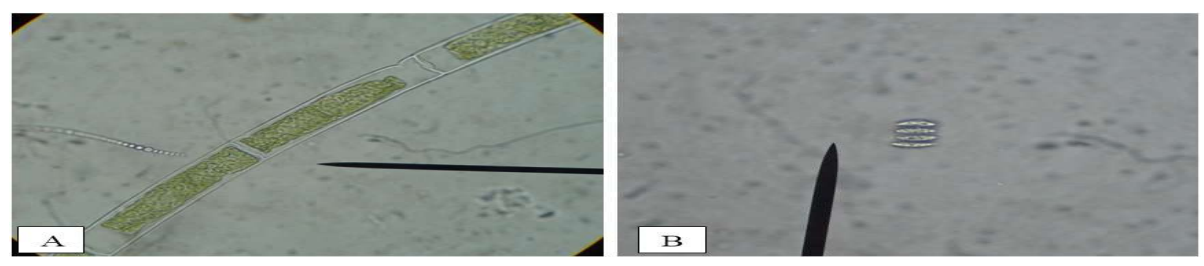

Figure 8. Genera of common green algae (Chlorophyceae) in Brgy. Biasong (A. Groenbladia B. Scenedesmus, 400X) 
For the benthic forms, profuse growth of Cladophora (Figure 9) on rocks was observed. The filaments of the alga were very long and healthy, part of the thalli adhered tightly on the rocks and stones (Figure 10). During sampling time, the water was clean and crystal clear, so the alga was readily observable above the water surface. Literatures have indicated that the genus is an indicator of clean water.

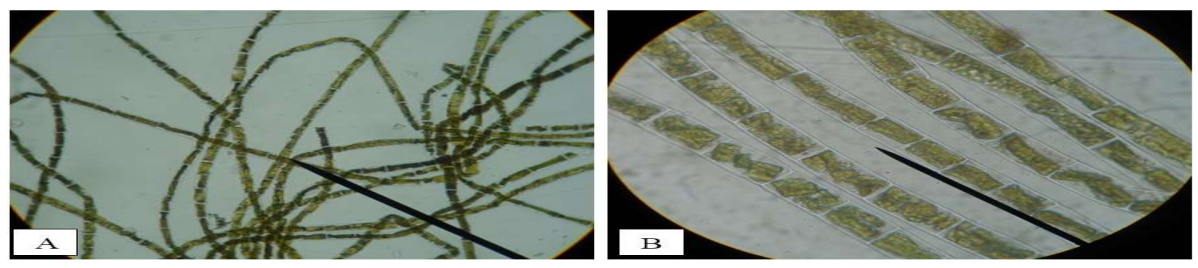

Figure 9. Genera of widely occurring benthic algae under Chlorophyceae - Cladophora viewed under (A.LPO-100x; B. HPO-400x)

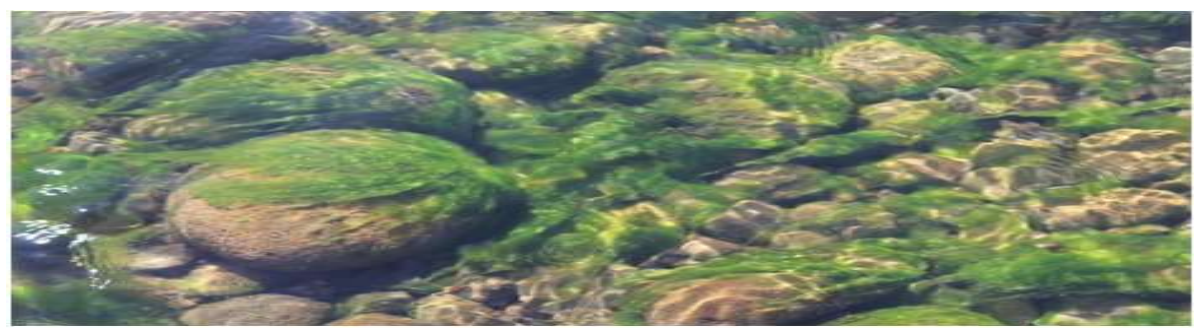

Figure 10. Profuse growth of Cladophora on rocks in Site 2, Brgy. Biasong

The zooplankton was composed of all four major groups, insect and non-insect larvae with a total of 14 families identified (Table 2). For the true zooplankton, seven families with five genera were recorded. These were Daphniidae, Harpacticoida, Cyclopidae, Brachioniidae, Lecanidae, Mytilinidae and Testudinellidae. For the meroplankton, five insect larvae groups with five families were noted in this site. These were Coleoptera, Diptera, Ephemeroptera, Megaloptera and Trichoptera. Arachnida and fish larvae were also present.

\section{Site 3. Brgy. Palhi}

The downstream portion of the river, located in Brgy. Palhi, produced 23 representative genera belonging to three classes (Table 1). Bacillariophyceae had the most (12) number of genera of algae, followed by Chlorophyceae with seven and, by Cyanophyceae, four.

In Bacillariophyceae, there were three widely occurring genera in the sampling points. These were Biddulphia, Meridion, and Synedra (Figure 11). In Chlorophyceae, the common alga was Groenbladia (Figure 12a) while in Cyanophyceae, it was dominated by Nostoc (Figure 12b).

The true zooplankton in Site 3 had a total of seven families with five genera as shown in Table 2. These were Daphniidae, Cyclopidae, Harpacticoida, Brachioniidae, Lecanidae, Mytilinidae, and Testudinellidae. 
There were only two insect groups identified, the Diptera and the Ephemeroptera with three families, Chironomidae, Simuliidae and Baetidae (Table 2). Family Hydracnidae and a gastropod larvae were also noted to be present as non-insect group larvae.
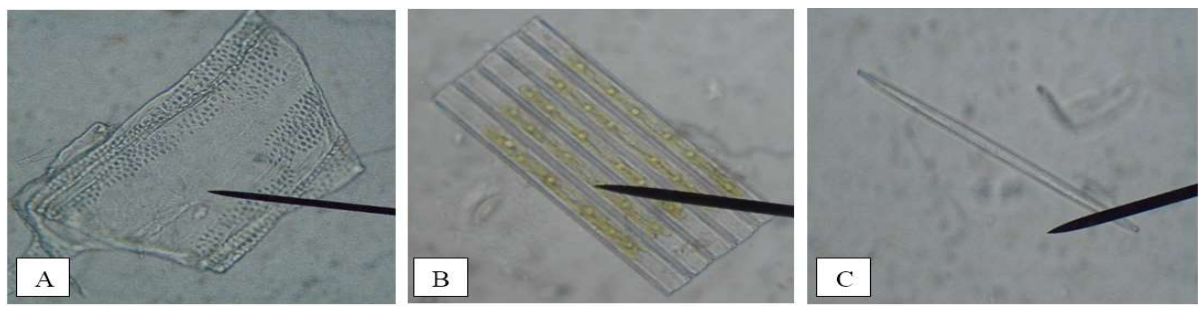

Figure 11. Genera of widely occurring diatoms (Bacillariophyceae) in Brgy. Palhi (A. Biddulphia, B.Meridion, C.Synedra, 400X)
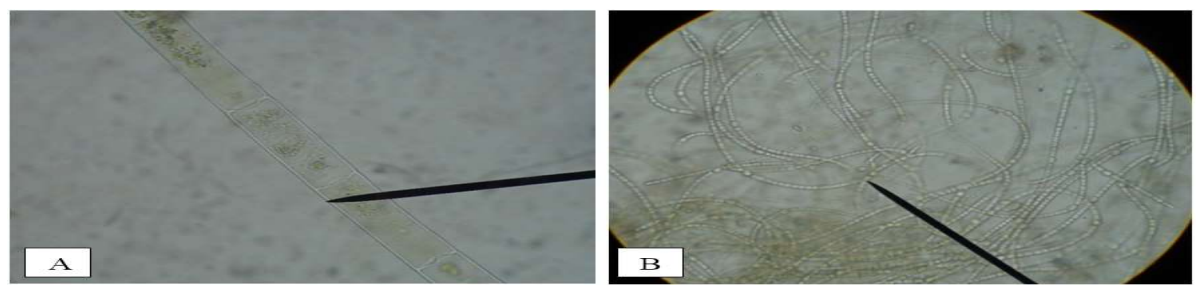

Figure 12. Genera of widely occurring species under Chlorophyceae (A. Groenbladia) and Cyanophyceae (B. Nostoc) in Brgy.Palhi, 400X

\section{Wet Season Sampling}

\section{Composition and Distribution}

Table 3 shows the occurrence of 165 free-floating (pelagic) algae belonging to 68 genera in seven different classes distributed across the three sites. While in Table 4, a total of 18 zooplankton belonging to different Orders and Families was recorded in all three sites.

Table 3. Occurrence of pelagic algae belonging to different classes collected during wet season from three sampling points in Brgys. Banahao, Biasong and Palhi

\begin{tabular}{lccccc}
\hline \multirow{2}{*}{ Class } & Genus/Species name & \multicolumn{3}{c}{ Occurrence } \\
\cline { 2 - 5 } Bacillariophyceae & Achnanthes & Site 1 & Site 2 & Site 3 \\
& Achnanthes conspicua & + & - & - \\
& Achnanthes exigua var.heterovalva & + & + & + \\
Achnanthes lanceolata & + & + & + \\
Amphora ovalis & + & + & + \\
Biddulphia laevis & + & + & + \\
& Closterium juncidum & - & - & + \\
Cyclotella & - & + & + \\
& Cymatopleura solea & + & - & + \\
Cymbella turgida & & + & + & + \\
\hline
\end{tabular}


Table 3. Continuation

\begin{tabular}{|c|c|c|c|c|}
\hline \multirow{2}{*}{ Class } & \multirow{2}{*}{ Genus/Species name } & \multicolumn{3}{|c|}{ Occurrence } \\
\hline & & Site 1 & Site 2 & Site 3 \\
\hline & Diatoma hiemale var.mesodon & + & + & + \\
\hline & Epithemia zebra & + & - & - \\
\hline & Epithemia zebra var. saxonica & + & + & + \\
\hline & Eunotia & + & + & + \\
\hline & Fragilaria construens var.pumila & + & + & + \\
\hline & Fragilaria virescens var.capitata & + & + & + \\
\hline & Frustulia & + & + & + \\
\hline & Gomphonema & - & + & + \\
\hline & Gomphonema constrictum var.capitata & + & + & + \\
\hline & Gomphonema subclavatum & - & + & + \\
\hline & Meridion circulare & + & + & + \\
\hline & Navicula & + & + & + \\
\hline & Navicula exigua & + & + & + \\
\hline & Neidium & + & - & - \\
\hline & Nitzschia fonticola & - & + & + \\
\hline & Opephora & + & + & - \\
\hline & Pinnularia & + & + & - \\
\hline & Pleurosigma & - & + & - \\
\hline & Rhopalodia gibba & - & + & - \\
\hline & Spirulina & - & - & + \\
\hline & Surirella & - & + & - \\
\hline & Synedra ulna & + & + & + \\
\hline & Synedra ulna var.contracta & + & - & + \\
\hline & Synedra ulna var. danica & + & + & + \\
\hline & Synedra ulna var.longissima & - & - & + \\
\hline & Tabellaria flocculosa & + & + & + \\
\hline \multirow[t]{2}{*}{ Charophyceae } & Chara (fragment) & + & + & - \\
\hline & Nitella (fragment) & + & + & - \\
\hline \multirow[t]{27}{*}{ Chlorophyceae } & Ankistrodesmus & + & + & - \\
\hline & Closterium & + & + & - \\
\hline & Closterium juncidum & - & + & - \\
\hline & Closterium lunula & - & - & + \\
\hline & Closterium pritchardianum & - & + & + \\
\hline & Coleochaete divergens & + & + & - \\
\hline & Coleochaete soluta & + & + & - \\
\hline & Cosmarium & + & + & + \\
\hline & Cosmarium subspeciosum & - & - & + \\
\hline & Cosmarium thwaitesii & - & - & + \\
\hline & Cosmocladium & + & - & - \\
\hline & Elakatothrix & - & + & + \\
\hline & Excentrosphaera & - & + & + \\
\hline & Geminella & - & - & - \\
\hline & Groenbladia neglecta & + & + & + \\
\hline & Groenbladia taylorii & + & - & - \\
\hline & Hyalotheca mucosa & + & + & + \\
\hline & Mesotaenium & + & + & + \\
\hline & Mesotaenium macrococcum & - & + & + \\
\hline & Micrasterias & + & + & - \\
\hline & Microspora willeana & + & - & + \\
\hline & Nannochloris bacillaris & + & + & + \\
\hline & Netrium & - & + & - \\
\hline & Penium cylindrus & + & - & - \\
\hline & Spirogyra & - & - & + \\
\hline & Staurastrum & - & + & + \\
\hline & Ulothrix & + & + & + \\
\hline
\end{tabular}


Table 3. Continuation

\begin{tabular}{|c|c|c|c|c|}
\hline \multirow{2}{*}{ Class } & \multirow{2}{*}{ Genus/Species name } & \multicolumn{3}{|c|}{ Occurrence } \\
\hline & & Site 1 & Site 2 & Site 3 \\
\hline \multirow[t]{3}{*}{ Chrysophyceae } & Eirmodesmus & - & + & - \\
\hline & Uroglenopsis & - & + & - \\
\hline & Synura & - & - & + \\
\hline \multirow[t]{13}{*}{ Cyanophyceae } & Amphithrix & - & - & + \\
\hline & Aphanothece & - & + & + \\
\hline & Calothrix & + & - & - \\
\hline & Cosmocladium & - & + & - \\
\hline & Dactylococcopsis raphidioides & + & - & - \\
\hline & Dichothrix & & + & + \\
\hline & Entophysalis & - & + & + \\
\hline & Merismopedia major & + & - & - \\
\hline & Nostoc & - & - & + \\
\hline & Oscillatoria & - & + & - \\
\hline & Polycystis & + & - & + \\
\hline & Spirulina & - & + & - \\
\hline & Trichodesmium laucustre & + & + & - \\
\hline Euglenophyceae & Trachelomonas & - & + & + \\
\hline \multirow{3}{*}{ Rhodophyceae } & Hildenbrandia & + & - & - \\
\hline & Rhodochorton(fragment) & + & - & - \\
\hline & Total Number of Pelagic Algae (Genera) & $\begin{array}{c}52 \\
(41)\end{array}$ & $\begin{array}{c}59 \\
(49)\end{array}$ & $\begin{array}{c}54 \\
(41) \\
\end{array}$ \\
\hline
\end{tabular}

In Site 1, Brgy. Banahao, 52 free-floating algae in 41 genera and five classes were collected. The five classes included Bacillariophyceae, Charophyceae, Chlorophyceae, Cyanophyceae, and Rhodophyceae. Of the five classes, Bacillariophyceae got the most number (26) of representative pelagic algae with 18 genera, followed by Chlorophyceae (17) with 14 genera, then by Cyanophyceae (5) with 5 genera, Charophyceae (2) and Rhodophyceae (2) with two genera each. In terms of number of individuals, Table 4 shows that Cymbella turgida in Class Bacillariophyceae was the most dense (336) followed by Fragilaria construens (268) and lastly, F. virescens (204). All were found present in three sampling points, right, left and middle. In Chlorophyceae, Mesotaenium ranked first (144) having the highest number of individuals, followed by Hyalotheca mucosa (100), then by Ulothrix (58). Coloechaete solute was given a numerical description plenty, because the vegetative cells are clump in colony by mucilage, unabling the individual cells to be counted. In Cyanophyceae, there was plenty of Polycystis, followed by Merismopedia (26).

For the zooplankton, there were five holoplankton families identified with four genera. These were Daphniidae, Harpacticoida, Mytiliniidae, Lecanidae and Testudinellidae. Three insect groups, Diptera, Ephemeroptera and Plecoptera were noted present. Each group was represented with one family (Table 5). Hydrachnidae represented the noninsect group and was found at the middle portion of the river.

In Site 2, Brgy. Biasong, the 59 pelagic algae (Table 3) belonging to 49 genera were classified under six classes. These included Bacillariophyceae, with the highest number (28) of pelagic algae and 22 representative genera, followed by Chlorophyceae with 19, classified in 15 
genera, Cyanophyceae with seven in seven genera. Charophyceae and Chrysophyceae had two each in two genera while Euglenophyceae had one collected alga in one genus. In Bacillariophyceae, Fragilaria construens ranked first (63) in terms of number of individuals, followed by Cymbella turgida and Diatoma hiemale (41), and then, Amphora ovalis (39). In the group of the greens, the highest number of individual algae was observed in Excentrosphaera (86). This was followed by Elakatothrix (78) and thirdly, by Mesotaenium (64). For blue-greens, Entophysalis got the most number of individual algae (78), followed by Spirulina (26), then Oscillatoria (11) (Table 4).

Table 4. Composition, distribution and abundance (Relative Density, (\%) of pelagic algae belonging to different classes collected from three sampling points in Brgys. Banahao, Biasong and Palhi during wet season

\begin{tabular}{|c|c|c|c|c|c|c|c|}
\hline \multirow{2}{*}{ Class } & \multirow{2}{*}{ Genus/Species name } & \multicolumn{3}{|c|}{ Number of Individuals } & \multirow{2}{*}{$\begin{array}{l}\text { Total No. of } \\
\text { Individuals }\end{array}$} & \multirow{2}{*}{$\begin{array}{l}\text { Relative } \\
\text { Density } \\
\text { (RD \%) } \\
\text { (Class) }\end{array}$} & \multirow{2}{*}{$\begin{array}{c}\text { Relative } \\
\text { Density } \\
\text { (RD \%) } \\
\text { (Site) }\end{array}$} \\
\hline & & Site 1 & Site 2 & Site 3 & & & \\
\hline \multirow[t]{35}{*}{ Bacillariophyceae } & Achnanthes & 2 & - & - & 2 & 0.08 & 0.05 \\
\hline & Achnanthes conspicua & 90 & 27 & 21 & 138 & 5.37 & 3.36 \\
\hline & $\begin{array}{c}\text { Achnanthes exigua } \\
\text { var. heterovalva }\end{array}$ & 123 & 17 & 21 & 161 & 6.27 & 3.92 \\
\hline & Achnanthes lanceolata & 16 & 1 & 5 & 22 & 0.86 & 0.54 \\
\hline & Amphora ovalis & 55 & 39 & 9 & 103 & 4.01 & 2.51 \\
\hline & Biddulphia laevis & 15 & 3 & 2 & 20 & 0.78 & 0.49 \\
\hline & Closterium juncidum & - & - & 18 & 18 & 0.7 & 0.44 \\
\hline & Cyclotella & - & 7 & 16 & 23 & 0.9 & 0.56 \\
\hline & Cymatopleura solea & 5 & - & 1 & 6 & 0.23 & 0.15 \\
\hline & Cymbella turgida & 336 & 41 & 15 & 392 & 15.26 & 9.54 \\
\hline & $\begin{array}{c}\text { Diatoma hiemale var. } \\
\text { mesodon }\end{array}$ & 79 & 41 & 21 & 141 & 5.49 & 3.43 \\
\hline & Epithemia zebra & 11 & - & - & 11 & 0.43 & 0.27 \\
\hline & $\begin{array}{c}\text { Epithemia zebra var. } \\
\text { saxonica }\end{array}$ & 23 & 11 & 3 & 37 & 1.44 & 0.9 \\
\hline & Eunotia & 54 & 25 & 10 & 89 & 3.46 & 2.17 \\
\hline & $\begin{array}{l}\text { Fragilaria construens } \\
\text { var. pumila }\end{array}$ & 268 & 63 & 19 & 350 & 13.62 & 8.52 \\
\hline & $\begin{array}{l}\text { Fragilaria virescens } \\
\text { var. capitata }\end{array}$ & 204 & 27 & 23 & 254 & 9.89 & 6.18 \\
\hline & Frustulia & 114 & 5 & 53 & 172 & 6.7 & 4.18 \\
\hline & $\begin{array}{l}\text { Gomphonema } \\
\text { Gomphonema }\end{array}$ & - & 12 & 3 & 15 & 0.58 & 0.37 \\
\hline & $\begin{array}{l}\text { constrictum var. } \\
\text { capitata }\end{array}$ & 61 & 2 & 2 & 65 & 2.53 & 1.58 \\
\hline & $\begin{array}{l}\text { Gomphonema } \\
\text { subclavatum }\end{array}$ & - & 1 & 4 & 5 & 0.19 & 0.12 \\
\hline & Meridion circulare & 59 & 17 & 13 & 89 & 3.46 & 2.17 \\
\hline & Navicula & 9 & 5 & 3 & 17 & 0.66 & 0.41 \\
\hline & Navicula exigua & 133 & 16 & 13 & 162 & 6.31 & 3.94 \\
\hline & Neidium & 4 & - & - & 4 & 0.16 & 0.1 \\
\hline & Nitzschia fonticola & - & 3 & 1 & 4 & 0.16 & 0.1 \\
\hline & Opephora & 4 & 1 & - & 5 & 0.19 & 0.12 \\
\hline & Pinnularia & 48 & 11 & 14 & 73 & 2.84 & 1.78 \\
\hline & Pleurosigma & - & 2 & - & 2 & 0.08 & 0.05 \\
\hline & Rhopalodia gibba & - & 1 & - & 1 & 0.04 & 0.02 \\
\hline & Spirulina & - & - & 5 & 5 & 0.19 & 0.12 \\
\hline & Surirella & - & 3 & - & 3 & 0.12 & 0.07 \\
\hline & Synedra ulna & 27 & 27 & 23 & 77 & 3 & 1.87 \\
\hline & $\begin{array}{l}\text { Synedra ulna } \\
\text { var.contracta }\end{array}$ & 9 & - & 2 & 11 & 0.43 & 0.27 \\
\hline & $\begin{array}{l}\text { Synedra ulna var. } \\
\text { danica }\end{array}$ & 18 & 6 & 1 & 25 & 0.97 & 0.61 \\
\hline & $\begin{array}{c}\text { Synedra ulna } \\
\text { var.longissima }\end{array}$ & - & - & 1 & 1 & 0.04 & 0.02 \\
\hline
\end{tabular}


Table 4. Continuation

\begin{tabular}{|c|c|c|c|c|c|c|c|}
\hline \multirow{2}{*}{ Class } & \multirow{2}{*}{ Genus/Species name } & \multicolumn{3}{|c|}{ Number of Individuals } & \multirow{2}{*}{$\begin{array}{l}\text { Total No. of } \\
\text { Individuals }\end{array}$} & \multirow{2}{*}{$\begin{array}{l}\text { Relative } \\
\text { Density } \\
\text { (RD \%) } \\
\text { (Class) } \\
\end{array}$} & \multirow{2}{*}{$\begin{array}{c}\text { Relative } \\
\text { Density } \\
\text { (RD \%) } \\
\text { (Site) }\end{array}$} \\
\hline & & Site 1 & Site 2 & Site 3 & & & \\
\hline \multirow[t]{2}{*}{ Bacillariophyceae } & Tabellaria flocculosa & 45 & 8 & 13 & 66 & 2.57 & 1.61 \\
\hline & SUBTOTAL & 1812 & 422 & 335 & 2569 & & \\
\hline \multirow[t]{3}{*}{ Charophyceae } & Chara (fragment) & 2 & 2 & - & 4 & 66.67 & 0.1 \\
\hline & Nitella (fragment) & 1 & 1 & - & 2 & 33.33 & 0.05 \\
\hline & SUBTOTAL & 3 & 3 & $\mathbf{0}$ & 6 & & \\
\hline \multirow[t]{32}{*}{ Chlorophyceae } & Ankistrodesmus & 5 & 8 & 1 & 14 & 1.08 & 0.34 \\
\hline & Closterium & 45 & 3 & - & 48 & 3.7 & 1.17 \\
\hline & Closterium juncidum & - & 17 & - & 17 & 1.31 & 0.41 \\
\hline & Closterium lunula & - & - & 2 & 2 & 0.15 & 0.05 \\
\hline & $\begin{array}{c}\text { Closterium } \\
\text { pritchardianum }\end{array}$ & - & 2 & 1 & 3 & 0.23 & 0.07 \\
\hline & Coleochaete divergens & 1 & 3 & - & 4 & 0.31 & 0.1 \\
\hline & Coleochaete soluta & plenty & plenty & - & plenty & - & - \\
\hline & Cosmarium & 22 & 17 & 10 & 49 & 3.77 & 1.19 \\
\hline & $\begin{array}{c}\text { Cosmarium } \\
\text { subspeciosum }\end{array}$ & - & - & 1 & 1 & 0.08 & 0.02 \\
\hline & Cosmarium thwaitesii & - & - & 2 & 2 & 0.15 & 0.05 \\
\hline & Cosmocladium & 3 & - & - & 3 & 0.23 & 0.07 \\
\hline & Elakatothrix & - & 78 & 48 & 126 & 9.69 & 3.07 \\
\hline & Excentrosphaera & - & 86 & 120 & 206 & 15.85 & 5.01 \\
\hline & Geminella & - & - & 2 & 2 & 0.15 & 0.05 \\
\hline & Groenbladia neglecta & 11 & 11 & 10 & 32 & 2.46 & 0.78 \\
\hline & Groenbladia taylorii & 33 & - & - & 33 & 2.54 & 0.8 \\
\hline & Hyalotheca mucosa & 100 & 7 & 7 & 114 & 8.77 & 2.77 \\
\hline & Mesotaenium & 144 & 64 & 48 & 256 & 19.7 & 6.23 \\
\hline & $\begin{array}{l}\text { Mesotaenium } \\
\text { macrococcum }\end{array}$ & - & 46 & 56 & 102 & 7.85 & 2.48 \\
\hline & Micrasterias & 2 & 27 & - & 29 & 2.23 & 0.71 \\
\hline & Microspora willeana & 6 & - & 4 & 10 & 0.77 & 0.24 \\
\hline & $\begin{array}{l}\text { Nannochloris } \\
\text { bacillaris }\end{array}$ & 19 & 15 & 21 & 55 & 4.23 & 1.34 \\
\hline & Netrium & - & 18 & - & 18 & 1.38 & 0.44 \\
\hline & Peniumcylindrus & 5 & - & - & 5 & 0.38 & 0.12 \\
\hline & Phymatodocis & - & - & 1 & 1 & 0.08 & 0.02 \\
\hline & $\begin{array}{c}\text { Pleurotaenium } \\
\text { trochiscum }\end{array}$ & - & 7 & - & 7 & 0.54 & 0.17 \\
\hline & Scenedesmus obliquus & 3 & - & - & 3 & 0.23 & 0.07 \\
\hline & $\begin{array}{l}\text { Scenedesmus } \\
\text { quadricauda }\end{array}$ & 1 & - & 1 & 2 & 0.15 & 0.05 \\
\hline & $\begin{array}{l}\text { Oedogonium } \\
\text { undulatum }\end{array}$ & - & - & 51 & 51 & 3.92 & 1.24 \\
\hline & Staurastrum & - & 1 & 2 & 3 & 0.23 & 0.07 \\
\hline & Ulothrix & 58 & 4 & 40 & 102 & 7.85 & 2.48 \\
\hline & SUBTOTAL & 458 & 414 & 428 & 1300 & & \\
\hline \multirow[t]{4}{*}{ Chrysophyceae } & Eirmodesmus & - & plenty & - & plenty & - & - \\
\hline & Uroglenopsis & - & 1 & - & 1 & 12.5 & 0.0002 \\
\hline & Synura & - & - & 7 & 7 & 87.5 & 0.0017 \\
\hline & SUBTOTAL & $\mathbf{0}$ & 1 & 7 & 8 & & \\
\hline \multirow[t]{14}{*}{ Cyanophyceae } & Amphithrix & - & - & 1 & 1 & 0.45 & 0.02 \\
\hline & Aphanothece & - & 6 & 3 & 9 & 4.07 & 0.22 \\
\hline & Calothrix & 5 & - & - & 5 & 2.26 & 0.12 \\
\hline & Cosmocladium & - & 5 & - & 5 & 2.26 & 0.12 \\
\hline & $\begin{array}{l}\text { Dactylococcopsis } \\
\text { raphidioides }\end{array}$ & 3 & - & - & 3 & 1.36 & 0.07 \\
\hline & Dichothrix & & 8 & 1 & 9 & 4.07 & 0.22 \\
\hline & Entophysalis & - & 78 & 19 & 97 & 43.89 & 2.36 \\
\hline & Merismopedia major & 26 & - & - & 26 & 11.77 & 0.63 \\
\hline & Nostoc & - & - & 21 & 21 & 9.5 & 0.51 \\
\hline & Oscillatoria & - & 11 & - & 11 & 4.98 & 0.27 \\
\hline & Polycystis & plenty & - & plenty & plenty & - & - \\
\hline & Spirulina & - & 26 & - & 26 & 11.77 & 0.63 \\
\hline & $\begin{array}{l}\text { Trichodesmium } \\
\quad \text { laucustre }\end{array}$ & 5 & 3 & - & 8 & 3.62 & 0.19 \\
\hline & SUBTOTAL & 39 & 137 & 45 & 221 & & \\
\hline
\end{tabular}


Table 4. Continuation

\begin{tabular}{|c|c|c|c|c|c|c|c|}
\hline \multirow[b]{2}{*}{ Class } & \multirow[b]{2}{*}{ Genus/Species name } & \multicolumn{3}{|c|}{ Number of Individuals } & \multirow{2}{*}{$\begin{array}{l}\text { Total No. of } \\
\text { Individuals }\end{array}$} & \multirow{2}{*}{$\begin{array}{l}\text { Relative } \\
\text { Density } \\
\text { (RD \%) } \\
\text { (Class) } \\
\end{array}$} & \multirow{2}{*}{$\begin{array}{c}\text { Relative } \\
\text { Density } \\
\text { (RD \%) } \\
\text { (Site) }\end{array}$} \\
\hline & & Site 1 & Site 2 & Site 3 & & & \\
\hline \multirow[t]{2}{*}{ Euglenaceae } & Trachelomonas & - & 3 & 1 & 4 & 100 & 0.1 \\
\hline & SUBTOTAL & $\mathbf{0}$ & 3 & 1 & 4 & & \\
\hline \multirow[t]{3}{*}{ Rhodophyceae } & Hildenbrandia & 1 & - & - & 1 & 50 & 0.02 \\
\hline & $\begin{array}{l}\text { Rhodochorton } \\
\text { (fragment) }\end{array}$ & 1 & - & - & 1 & 50 & 0.02 \\
\hline & $\begin{array}{l}\text { SUBTOTAL } \\
\text { T O T A L }\end{array}$ & $\begin{array}{c}2 \\
2314\end{array}$ & $\begin{array}{c}\mathbf{0} \\
\mathbf{9 8 0}\end{array}$ & $\begin{array}{c}0 \\
816\end{array}$ & $\begin{array}{c}2 \\
4110\end{array}$ & & \\
\hline
\end{tabular}

A total of nine families of zooplankton were distributed in this site. Six belong to holoplankton while three represented the meroplankton. The true plankton included Daphniidae, Harpacticoida, Bdelloidea, Lecanidae, Mytilinidae and Testudinellidae while insect groups were represented by Diptera, Ephemeroptera and Plecoptera (Table 5).

For Site 3, Brgy. Palhi, the 54 free-floating algae sampled (Table 3) were classified under 41 genera belonging to five classes. These were Bacillariophyceae with 28 free-floating algae belonging to 19 genera, Chlorophyceae with 18 pelagics in 14 genera, Cyanophyceae had six representatives in six genera, and one each in Chrysophyceae with two genera and Euglenophyceae with one genus. For diatoms, Frustulia had the highest (53) figure of individual algae, followed by Fragilaria virescens and Synedra ulna (23), then by Achnanthes and Diatoma (21). For the greens, Excentrosphaera ranked first (120), Mesotaenium macrococcum, second (56) and Oedogonium undulatum, third (51) (Table 4).

This site harbors the most number of zooplankton for this season. A total of 12 families were identified (Table 5). Seven of them, belong to true zooplankton which included Daphniidae, Cyclopoida, Harpacticoida, Brachioniidae, Lecanidae, Proalidae and Testudinellidae. For the insect groups, it was represented with Diptera, Ephemeroptera, Plecoptera and Trichoptera. A non-insect group, the amphipod, under Family Gammaridae was also observed to be frequently occurring and was found in all three sampling points. Gastropod larvae were also noted in this site (Figure 13).

Table 5. Occurrence of zooplankton collected during the wet season across all sites

\begin{tabular}{|c|c|c|c|c|c|}
\hline Major Taxon & Family & Genus & Site 1 & Site 2 & Site 3 \\
\hline \multicolumn{6}{|l|}{ Holoplankton } \\
\hline Cladocera & Daphniidae & Daphnia & + & + & + \\
\hline \multirow[t]{3}{*}{ Copepoda } & Cyclopidae & & - & - & + \\
\hline & Harpacticoida & & + & + & + \\
\hline & Nauplius & & + & + & + \\
\hline \multirow[t]{6}{*}{ Rotifera } & Bdelloidea & & - & + & - \\
\hline & Brachionidae & Brachionus & - & - & + \\
\hline & Lecanidae & Lecane & + & + & + \\
\hline & Mytilinidae & Mytilina & + & + & - \\
\hline & Proalidae & & - & - & + \\
\hline & Testudinellidae & Testudinella & + & + & + \\
\hline Protozoa & & & + & - & - \\
\hline Total Number & & & 8 & 7 & 8 \\
\hline
\end{tabular}


Table 5. Continuation

\begin{tabular}{|c|c|c|c|c|c|}
\hline Major Taxon & Family & Genus & Site 1 & Site 2 & Site 3 \\
\hline \multicolumn{6}{|l|}{$\begin{array}{l}\text { Meroplankton } \\
\text { Insect Groups }\end{array}$} \\
\hline Diptera & Chironomidae & & + & + & + \\
\hline Ephemeroptera & Baetidae & & + & + & + \\
\hline Plecoptera & Capniidae & & + & + & + \\
\hline Trichoptera & & & - & - & + \\
\hline \multicolumn{6}{|l|}{ Non-insect groups } \\
\hline Amphiphoda & Gammaridae & & - & - & + \\
\hline Arachnida & Hydrachnidae & & + & - & - \\
\hline Gastropod larvae & & & - & - & + \\
\hline Total Number & & & 5 & 3 & 6 \\
\hline Overall Total & & & 13 & 10 & 14 \\
\hline
\end{tabular}

Legend: + Present; - Absent
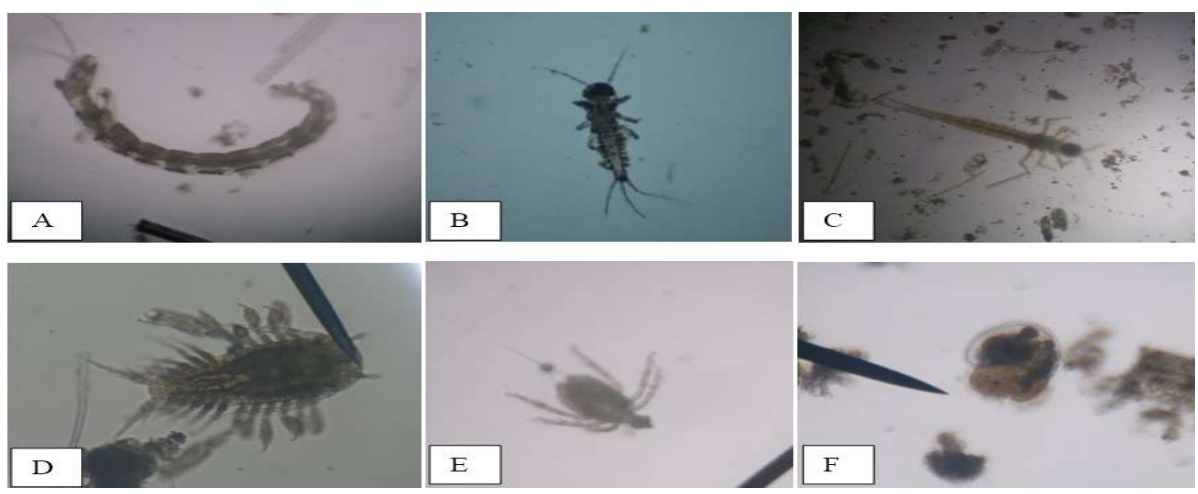

Figure 13. Representatives of meroplankton. Insects groups: A. Diptera, B. Ephemeroptera and C. Plecoptera and non-insect groups: D. Amphipoda, E. Archnida and F. Gastropod larvae in Brgy. Banahao, Brgy. Biasong and Brgy, Palhi (Total Magnification: 100x)

\section{Abundance}

An ecological measure of species abundance is relative density (\%), defined as the number of individuals (density) of a species as a percent of the total number of all individuals (total pelagic algae density) collected. This parameter is vital to determine which among the different algae samples collected is the most significant.

Across three sites (Table 4), the algae with the highest relative density were Cymbella turgida (9.54\%), followed by Fragilaria construens (8.52\%), then by Mesotaenium (6.23\%). Figure 14 showed the structural habit of the three most common algae with highest relative density. There were algae that were recorded plenty, occupying the whole field of vision of the microscope. They could not be counted individually because the vegetative cells were held together by mucilaginous substances, occurring in clumps or colonies. These were Coleochaete soluta, Eirmodesmus, and Polycystis.

Figure 15 showed the 10 most common genera/species of free-floating algae having the highest relative density in classes Bacillariophyceae, 
Chlorophyceae and Cyanophyceae. The relative densities of the ten most common genera/species of pelagic algae sampled in the three sites from all classes are presented in Figure 16. The classes or groups of algae having the most number of genera and species of free-floating algae sampled from Banahao, Biasong and Palhi are in Figure 17.

Abundance of zooplankton was expressed in number of individuals per cubic meter (m3). The most abundant group observed was Cyclopoida (5.20 per $\mathrm{m}^{3}$ ) followed by Harpacticoida $\left(4.55\right.$ per $\left.\mathrm{m}^{3}\right)$, which though present in all sites was observed highest in Brgy. Palhi. Both copepods also obtained the highest densities in this site (Figure 18). The third on the list was the Daphnia (2.53 per $\mathrm{m}^{3}$ ) followed by Rotifera of Family Lecanidae (2.49 per $\mathrm{m}^{3}$ ), Brachionidae (1.85 per $\mathrm{m}^{3}$ ) and Testudinellidae (1.39 per $\mathrm{m}^{3}$ ). The abundance of Families Brachionidae, Lecanidae, Proalidae and Testudinellidae in all sites could indicate the sensitivity of these rotifers to environmental changes that is why they are used as indicators of water quality (Gannon and Stremberger, 1978 in Goswani and Mankodi, 2012).

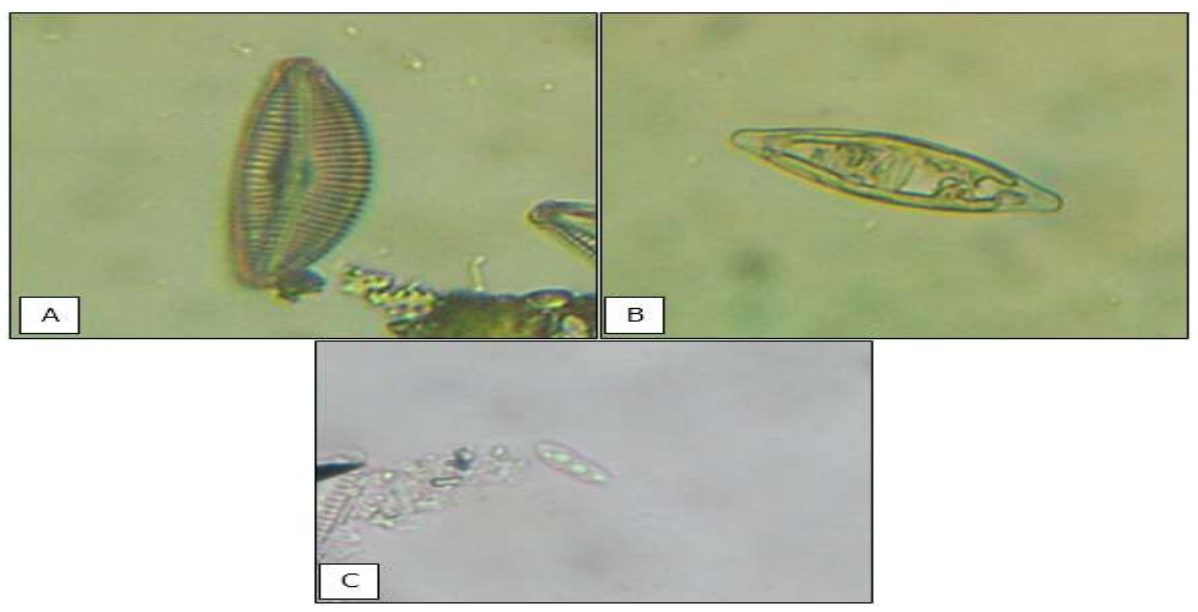

Figure 14. Pelagic algae with highest relative density (A. Cymbella turgida RD = 9.54\%; B. Fragilaria construens $\mathrm{RD}=8.52 \%$; C. Mesotaenium $\mathrm{RD}=6.23 \%$ )

\section{Environmental Parameters}

The physico-chemical parameters in the three sampling sites are shown in Table 6. Air temperature was recorded highest in Brgy. Banahao $\left(30^{\circ} \mathrm{C}\right)$, followed by Brgy. Biasong $\left(28.33^{\circ} \mathrm{C}\right)$ and lastly, in Brgy. Palhi $\left(27^{\circ} \mathrm{C}\right)$. For water temperature, highest value was observed in Brgy. Biasong and Brgy. Palhi $\left(30^{\circ} \mathrm{C}\right)$ while the least value was recorded in Brgy. Banahao $\left(27.89^{\circ} \mathrm{C}\right)$. The three sites tend to have a neutral water $\mathrm{pH}$, however, there was a slight difference in their values observed. Brgy. Banahao and Brgy. Biasong both have $\mathrm{pH}=7$ while Bgry. Palhi had $\mathrm{pH}=7.33$. The velocity or current speed of water in Brgy. Biasong was noted highest among the three sites with the value of $5.22 \mathrm{~m} / \mathrm{s}$, followed by Brgy. Banahao with a value of $3.77 \mathrm{~m} / \mathrm{s}$ and the least, was observed in Brgy. Palhi, $2.84 \mathrm{~m} / \mathrm{s}$. 


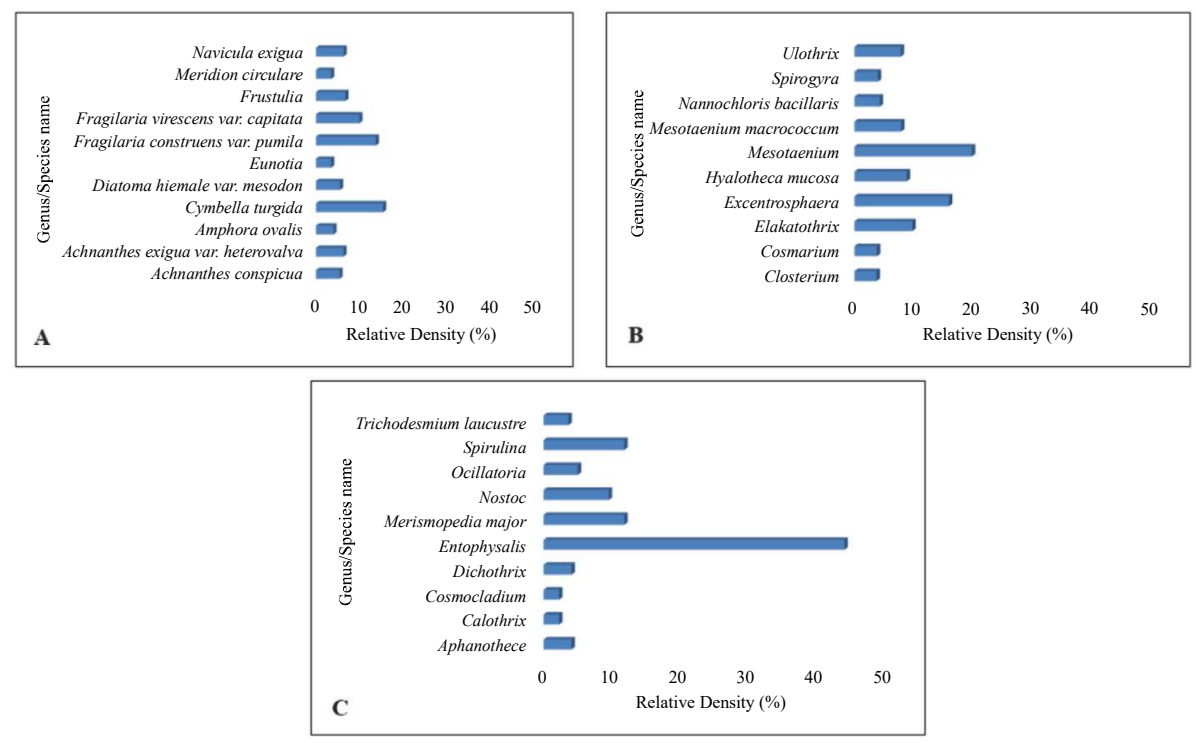

Figure 15. Ten most common genera/species of pelagic algae belonging to classes (A.Bacillariophyceae; B. Chlorophyceae; C.Cyanophyceae) having the highest relative density $(\%)$

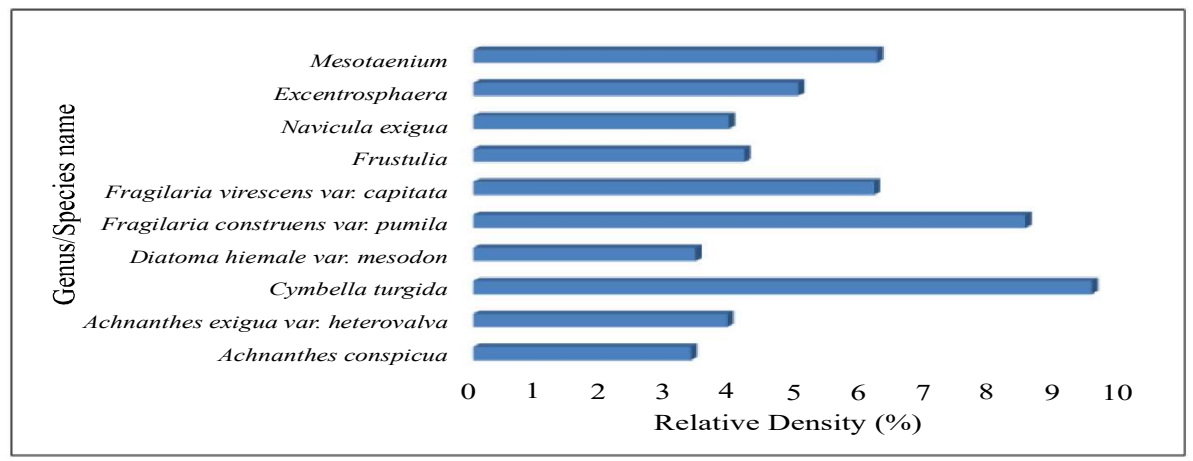

Figure 16. Ten most common genera/species of pelagic algae collected in three sites belonging to all classes having the highest relative density (\%)

\section{DISCUSSION}

Dry season sampling of plankton community in Banahao-Palhi river showed the presence of 99 pelagic or free-floating algae collected along the three sites of Barangays Banahao, Biasong and Palhi. The 58 genera belong to six classes namely, Bacillariophyceae, Charophyceae, Chlorophyceae, Chrysophyceae, Cyanophyceae and Rhodophyceae. Across sites, Class Bacillariophyceae, commonly known as diatoms, showed the highest number of genera in both seasons. During wet season, there was an increase in the number of free-floating algae (165), genera (68) and classes (7). These pelagic algae were collected in Classes namely: Bacillariophyceae, Charophyceae, Chlorophyceae, Chrysophyceae, Cyanophyceae, Euglenophyceae, and Rhodophyceae. The three genera 
common to all sites were Cymbella, Fragilaria and Mesotaenium. The first two belong to the group of diatoms, the last, to the greens. These three also got the highest relative density in all the sites.
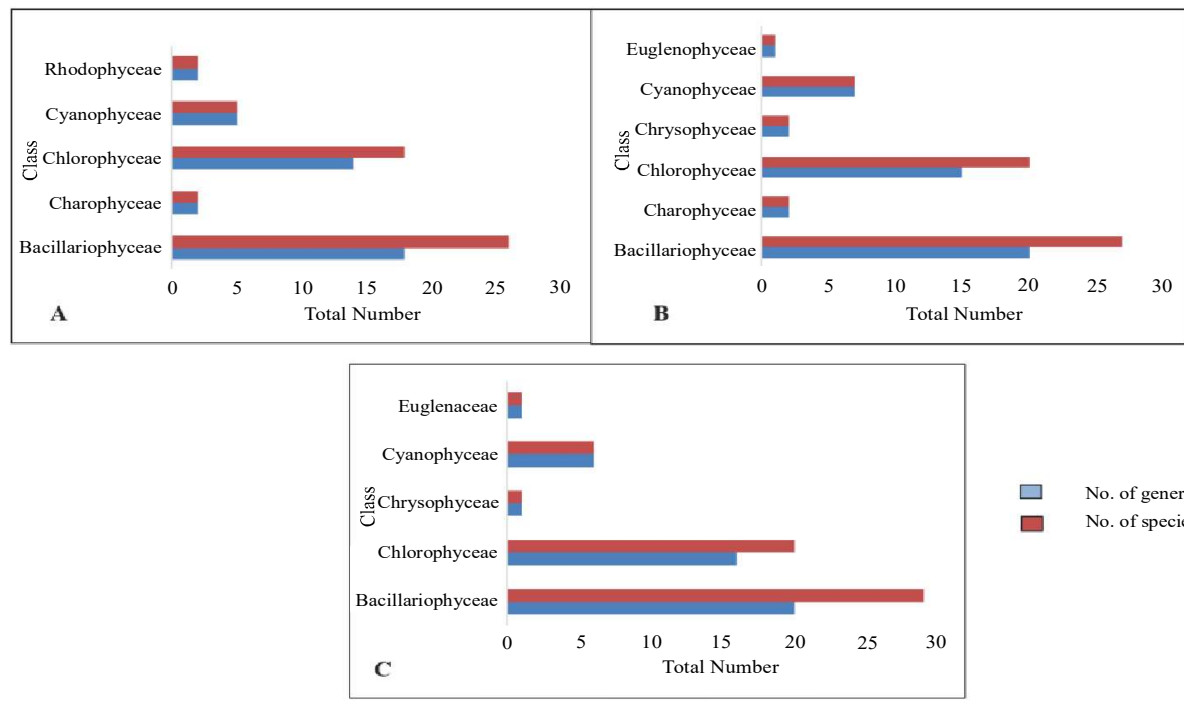

$\square \quad$ No. of genera

$\square \quad$ No. of species

Figure 17. Classes of pelagic algae present in the different barangays (A. Banahao; B. Biasong; C. Palhi) with the most number of genera and species

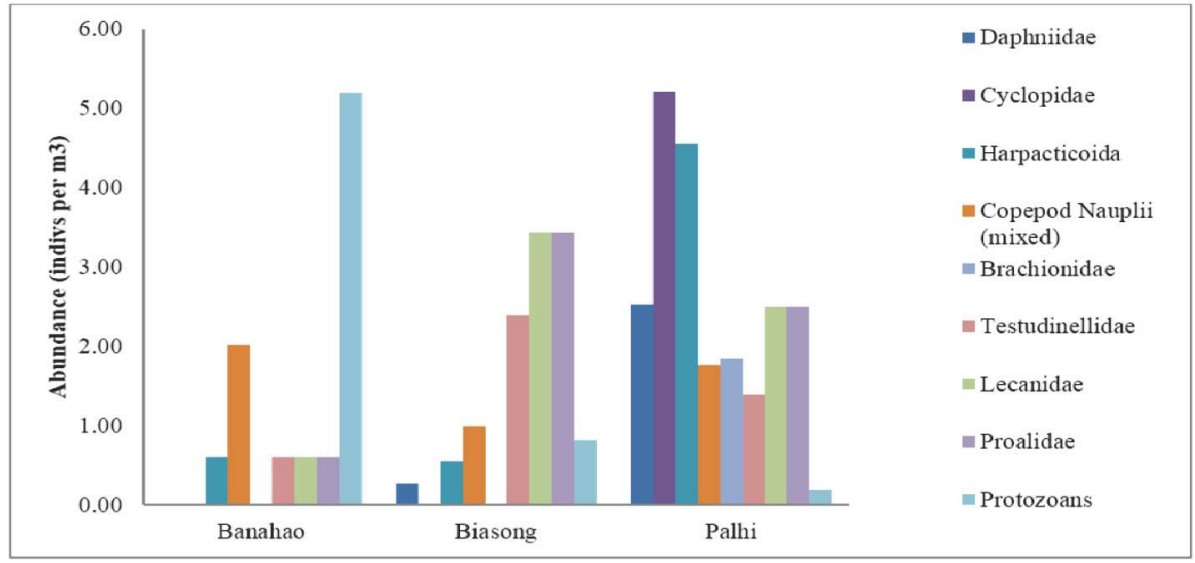

Figure 18. Abundance of true zooplankton collected during the wet season across all sites

Table 6. Physico-chemical parameters in the three sampling sites of Banahao-Palhi River, Baybay City Leyte

\begin{tabular}{ccccc}
\hline Sites & $\begin{array}{c}\text { Air Temperature } \\
\left({ }^{\circ} \mathrm{C}\right)\end{array}$ & $\begin{array}{c}\text { Water } \\
\text { temperature }\left({ }^{\circ} \mathrm{C}\right)\end{array}$ & $\mathrm{pH}$ & $\begin{array}{c}\text { Current speed } \\
(\mathrm{m} / \mathrm{s})\end{array}$ \\
\hline Banahao & 30.00 & 27.89 & 7 & 3.77 \\
Biasong & 28.33 & 30.00 & 7 & 5.22 \\
Palhi & 27.00 & 30.00 & 7.33 & 2.84 \\
\hline
\end{tabular}


The biology of planktonic diatoms in freshwater habitats, like river, typically exhibits a boom and bust (or "bloom and bust") lifestyle. When conditions in the upper mixed layer (nutrients and light) are favorable, their competitive edge allows them to quickly dominate phytoplankton communities ("boom" or "bloom). During the wet season, there was an increased number of phytoplankton collected which could have exhibited a bloom. This bloom may have been supported by the relative higher amount $(13.5 \mathrm{ppm})$ of total nitrogen $(\mathrm{N})$ nutrient and chlorophyll a $(14.080 \mathrm{ppm})$ gathered during that time in the study conducted by Yu and Salas (2016). According to them, the nitrogen level during this season was relatively higher than the tolerable limits set by the national and international standards. Although the data were collected at the midstream (Site 2 Brgy. Biasong) portion of the Banahao-Palhi River, this site also showed a relatively higher phytoplankton composition than those gathered from the upstream and downstream parts. When conditions turn unfavorable, usually upon depletion of nutrients, diatom cells typically increase in sinking rate and exit the upper mixed layer ("bust"). This sinking is induced by either a loss of buoyancy control, the synthesis of mucilage that sticks diatoms together or the production of heavy resting spores.

The five most frequently occurring pelagic algae found across sites included Biddulphia, Meridion, Synedra, Groenbladia and Nostoc. The first three, belong to the group of diatoms. The last two belong to the greens (Chlorophyceae) and blue-greens (Cyanophyceae), respectively. Again diatoms were found dominant because of their boom and bustlifestyle.

Aside from the favorable nutrient resources, other factor like grazing, could have possibly affected the cycle of the pelagic algae. The lesser occurrence of phytoplankton during the dry season may be explained by the presence of zooplankton organisms favorably feeding on the algae. Our data showed that the zooplankton community is represented more during the dry season compared with the wet season. The lesser zooplankton during the wet season could also mean less grazers which can be favorable for the growth of phytoplankton. However, it is important to thoroughly understand the type of relationship these two planktonic organisms has, as their occurrence can also be correlated to the type of environment they inhabit.

The occurrence of zooplankton is in synchrony with the presence of pelagic algae. During the dry season, zooplankton groups are mostly found in the left and the right sides of the river. These are also the sampling points where pelagic algae are recorded highest. The presence of phytoplankton could indicate food availability for these animal components of the plankton community.

Zooplankton are mostly grazers. Among the different sites, samples collected from Brgy. Palhi obtained the highest zooplankton composition with Family Daphniidae under Cladocera to be most frequently occurring. The presence of daphnids could possibly explain the lesser number of phytoplankton species in this particular area or site. Cladocerans, 
especially the large Daphnia, consume a wide variety of phytoplankton and other suspended matter, such as decompose material and clay particles. Their presence could have greatly reduced the abundance of phytoplankton.

Rotifera were frequently abundant in eutrophic freshwater ecosystem like Brgy. Palhi because of their short generation time and high productive rate. In general, the most abundant zooplankton were observed thriving in Brgy. Palhi because this site is close to an estuarine and a eutrophic (nutrient rich) zone as compared to Brgys. Banahao and Biasong. Brgy. Palhi is situated in a location where marine and freshwater meet. Estuarine environments are very productive which could provide a favorable habitat for growth of zooplankton. Cyclopoid copepods and cladocerans are well adapted to such eutrophic conditions which contribute to the relatively high abundance in Brgy. Palhi (Gannon and Stremberger, 1978 as cited by Goswani and Mankodi, 2012). Goswami and Mankodi (2012) stated further that the abundance of zooplankton depends largely on the availability of nutrients and the presence of these copepods could indicate a prey-predator relationships among zooplankton.

\section{ACKNOWLEDGMENT}

The researchers are grateful for the assistance given by Mesdames Jessa May T. Malanguis, Ella Mae L. Torino and Ilonah Jean A. Almanzor during field sample collection and laboratory analyses. This study was under the project entitled "Biological and Socio-ecological Characterization of Major River Systems in Leyte" with Dr. Beatriz S. Belonias as the project leader. This was funded by the Office of Research, Development and Extension, Visayas State University, Visca, Baybay City, Leyte.

\section{REFERENCES}

BOWLING, L. 2009. Freshwater phytoplankton: diversity and biology. In: Suthers, I. M. and D. Rissik. Plankton: A guide to their ecology and monitoring for water quality. CSIRO Publishing, Australia, pp 115-140.

FIELD GUIDE TO AQUATIC INVERTEBRATES. n.d. Retrieve from (http://www.dep.wv.gov/sos).

GOSWAMI, A.P. and P.C. MANKODI. 2012. Study on Zooplankton of Fresh Water Reservoir Nyari - II Rajkot district, Gujarat, India. ISCA Journal of Biological Sciences.

KOBAYASHI, T. SHIEL, R.J., KING, A.J. and A.G. MISKIEWICZ. 2009. Freshwater zooplankton: diversity and biology. In: Suthers, I. M. and D. Rissik. Plankton: A guide to their ecology and monitoring for water quality. CSIRO Publishing, Australia, pp157-179. 
LUDEVESE, H.L. 2005. Ecological survey of freshwater algae in Calbiga-a river in Pangasugan, Baybay, Leyte. BS thesis, Leyte State University, Visca, Baybay, Leyte.

SHIEL, R. J. 1995. A Guide to Identification of Rotifers, Cladocerans and Copepods from Australian Inland Waters. Cooperative Research Center for Freshwater Ecology, Murray-Darling Freshwater Research Center, Ellist Street, Thurgoona.

VALENZONA, R.E. 2005. Reconnaisance survey, collection and identification of freshwater algae along Lago-lago river, BS thesis, Leyte State University, Visca, Baybay, Leyte. VSU, Baybay, Leyte.

WHITFORD, L. A. and G.J. SCHUMACHER. 1973. A Manual of Freshwater Algae. Sparks Press, Raleigh, N.C.

WITTY, L. M. and D. RISSIK. 2004. Practical Guide to Identifying Freshwater Crustacean. Cooeprative Freshwater Ecology Unit. Ontario, Canada.

YU A. J. G. and F. M. SALAS. 2016. Pigmental composition of freshwater algae at different levels of nitrogen and physico-chemical parameters of Palhi River, Baybay, Leyte. Annals of Tropical Research 38 (1): 134147 